\title{
Decomposition dynamic of fine roots in a mixed forest of Cunninghamia lanceolata and Tsoongiodendron odorum in mid-subtropics
}

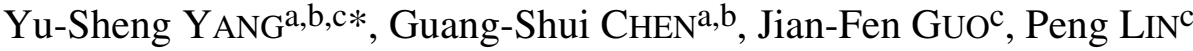 \\ a College of Geographical Science, Fujian Normal University, Fuzhou 350007, P.R. China \\ ${ }^{\mathrm{b}}$ College of Forestry, Fujian Agriculture and Forestry University, Nanping 353001, P.R. China \\ ${ }^{c}$ College of Life Science, Xiamen University, Xiamen 361005, P.R. China
}

(Received 22 April 2002; accepted 9 January 2003)

\begin{abstract}
Decomposition of fine roots ( $<2 \mathrm{~mm}$ in diameter, viz. $<0.5 \mathrm{~mm}, 0.5-1.0 \mathrm{~mm}, 1.0-2.0 \mathrm{~mm})$ was studied by means of litter bag in a mixed forest of Chinese fir (Cunninghamia lanceolata (Lamb.) Hook.) and Tsoong's tree (Tsoongiodendron odorum Chun) in Sanming, Fujian, China. In a $540 \mathrm{~d}$ period of decay, fine roots in all litter bags decomposed in a three-phase manner: (a) for the Chinese fir, an initial, relatively low rate of decay up to $90 \mathrm{~d}$ followed by a period of rapid weight loss until $270 \mathrm{~d}$, and then by a phase of slow decay rate; (b) for the Tsoong's tree, a rapid loss period between 0-60 d followed by a relatively rapid loss period between 60-360 d, and then a slow loss period between $360-$ $540 \mathrm{~d}$ occurred. The mass loss after 1 yr of decomposition ranged from 58.5\% to $63.3 \%$ for the Chinese fir and $68.8 \%$ to $78.2 \%$ for the Tsoong's tree. Fine roots with a larger diameter had a lower rate of mass loss. Consistent increase in lignin concentration and decrease in absolute amount of phosphorus $(\mathrm{P})$ were found for fine roots of the two tree species during decomposition. The absolute amounts of nitrogen $(\mathrm{N})$ increased a little initially in the fine roots of the Chinese fir during a short duration. In contrast, the fine roots of Tsoong's tree were releasing $\mathrm{N}$ from the outset. The chemical composition controlled decomposition rate and it was found a change of TNC (total nonstructural carbohydrates)-regulating in the initial decomposition phase to lignin- or N-regulating in the second phase, and P- or lignin-regulating in the last phase.
\end{abstract}

fine root / decomposition / lignin / nitrogen / phosphorus / mixed forest / Cunninghamia lanceolata / Tsoongiodendron odorum

Résumé - Dynamique de la décomposition des radicelles dans une forêt mélangée de Cunninghamia lanceolata et Tsoongiodendron odorum en zone subtropicale. On a étudié la décomposition de radicelles de diamètre inférieur à $2 \mathrm{~mm}(<0,5 \mathrm{~mm} ; 0,5$ à $1,0 \mathrm{~mm} ; 1,0$ à $2,0 \mathrm{~mm})$ en utilisant des sacs enterrés dans la litière, dans une forêt mélangée de sapin de Chine (Cunninghamia lanceolata (Lamb.) Hook) et d'arbres de Tsoong (Tsoongiodendron odorum Chun) située à Sanming, Fujian, Chine. Au cours des 540 jours d'observation de la dégradation des radicelles, leur décomposition s'est déroulée selon trois phases. a) Pour le sapin de Chine, on enregistre un taux initial de dégradation relativement lent jusqu'à 90 jours, puis une perte rapide de poids au cours de la période suivante allant jusqu'à 270 jours, et ensuite un taux de dégradation lent. b) Pour l'arbre de Tsoong, on constate une perte de poids rapide au cours des 60 premiers jours, puis une perte relativement rapide jusqu'à 360 jours et enfin une perte lente entre 360 et 540 jours. La perte de poids après 1 an de décomposition est comprise entre 58,5\% et $63,3 \%$ pour le sapin de Chine et entre $68,8 \%$ et $78,2 \%$ pour l'arbre de Tsoong. La perte de poids est moindre pour les radicelles les plus grosses. On note chez les deux espèces, au cours de la décomposition, une certaine augmentation du taux de lignine et une nette réduction du taux de phosphore. Pendant une courte période initiale, le taux d'azote augmente pour le sapin de Chine, alors que les radicelles de l'arbre de Tsoong libèrent de l'azote dès le début. La composition chimique commande le rythme de décomposition; on a mis en évidence les rôles respectifs des taux de carbohydrate total non structural (TNC), lignine (ou N) et P (ou lignine) au cours des différentes phases de la décomposition.

décomposition / lignine / azote / phosphore

\section{INTRODUCTION}

Chinese fir (Cunninghamia lanceolata (Lamb.) Hook.) is one of the most important plantation tree species in China in terms of planting area, yield, and timber usage. A great deal of monoculture Chinese fir plantations are established following forest land clearcutting, slash burning and soil preparation. However yield decline and land deterioration in such a disturbed ecosystem have become serious $[32,37]$. Tree species can exert some effects on soil fertility [3], and broadleaved species have been widely expected to be able to bring benefits to soil fertility in southern China $[32,36]$. Thus, introduction of broadleaved trees into coniferous plantations has been recommended as a practical measure to preserve long-term site productivity [32, 37]. Several studies have reported litterfall, nutrient cycling and soil fertility in mixed stands of Chinese fir and broadleaved trees $[17,25,32,33,34,36,37]$. With the recent emphasis placed on fine roots in forests, some mixed forests have been examined in China regarding biomass, productivity, distribution and the nutrient dynamics of fine roots.

* Corresponding author: ffcyys@ public.npptt.fj.cn 
However, there is scant information on fine root decomposition $[15,16,23,35]$.

Fine roots represent a large and dynamic entity of the below-ground biomass and nutrient capital, and a significant part of the net primary production of forest ecosystems [19, 30]. According to existing models, fine root mortality transfers significant amounts of organic matter and nutrients into the soil and is important in forest nutrient cycles [30]. Therefore, root decomposition is a key process in nutrient, mass and energy dynamics of forest ecosystems $[2,20]$. Fine roots contributed $25 \%-80 \%$ to the total soil carbon stock annually and $18 \% \sim 58 \%$ greater input of $\mathrm{N}$ to soil than aboveground leaf litter $[19,30]$; its turnover may be five times as much as that of aboveground litter is $[1,13]$. Thus, more studies on fine roots, combined with aboveground litter, are needed to have a better understanding of nutrient dynamics in forest ecosystems. The primary aims of this study were to (i) examine the pattern and rate of dry weight loss and nutrient release from decomposing fine roots of the Chinese fir and the Tsoong's tree, (ii) determine the relationship between decomposition rate and chemical composition during the three decay phases.

\section{MATERIALS AND METHODS}

\subsection{Site description}

The study was carried out from 1999 to 2000 in the Xiaohu work area of Xinkou Experimental Forestry Centre of Fujian Agricultural and Forestry University, Sanming, Fujian, China $\left(26^{\circ} 11^{\prime} 30^{\prime \prime} \mathrm{N}\right.$, $117^{\circ} 26^{\prime} 00^{\prime \prime}$ E). This area borders Daiyun Mountain on the southeast, with Wuyi Mountain on the northwest. The region has a middle subtropical monsoonal climate, with a mean annual temperature of $19.1{ }^{\circ} \mathrm{C}$ and a relative humidity of $81 \%$. The mean annual precipitation is $1749 \mathrm{~mm}$, mainly occurs from March to August. Mean annual evapotranspiration is $1585 \mathrm{~mm}$. The growing season is relatively long with an annual frost-free period of around $300 \mathrm{~d}$.

The sites have a northeast orientation and a $35^{\circ}$ slope; the forest studied is a mixed forest of Chinese fir and Tsoong's tree. The soil type is red soil derived from sandy Paleozoic shale, and its thickness exceeds $1.0 \mathrm{~m}$. Surface soil (0-20 cm depth) has organic matter (OM) content of $26.74 \mathrm{~g} \cdot \mathrm{kg}^{-1}$, total $\mathrm{N}$ of $1.180 \mathrm{~g} \cdot \mathrm{kg}^{-1}$, total $\mathrm{P}$ of $0.252 \mathrm{~g} \cdot \mathrm{kg}^{-1}$, humic carbon content of $8.595 \mathrm{~g} \cdot \mathrm{kg}^{-1}, \mathrm{C} / \mathrm{N}$ of 17.24 and $\mathrm{C} / \mathrm{P}$ of 81 [18]. In 1973, the mixed forest was planted with an initial planting density of 3000 stems $\cdot h^{-1}$. The mixed pattern is on strips, with three rows of Chinese fir and then one row of Tsoong's tree. At the time of survey (at age 27 a), the mixed stand had a density of 907 stems $\cdot \mathrm{ha}^{-1}$ for Chinese fir and 450 stems $\cdot$ ha $^{-1}$ for Tsoong's tree. The mean tree height and diameter at breast height (DBH) were $20.88 \mathrm{~m}$ and $25.1 \mathrm{~cm}$ for Chinese fir, and $17.81 \mathrm{~m}$ and $17.0 \mathrm{~cm}$ for Tsoong's tree, respectively. The canopy cover was $95 \%$ and the understory cover was $80 \%$.

\subsection{Fine root collection}

Fine roots $(<2 \mathrm{~mm}$ in diameter) of Chinese fir and Tsoong's tree were collected in the mixed forest by sieving from the upper $0-20 \mathrm{~cm}$ soil layer in May 1999, gently washed in tap water to remove adherent soil particles, and spread on a laboratory table to dry for $24 \mathrm{~h} \mathrm{[20].}$ Dead fine roots were discarded, and live fine roots of Chinese fir and Tsoong's tree were picked out, separated and further sorted into three size classes: $<0.5 \mathrm{~mm}, 0.5-1 \mathrm{~mm}$, and $1-2 \mathrm{~mm}$.

\subsection{Fine root decomposition}

The $18 \mathrm{~cm} \times 18 \mathrm{~cm}, 0.25-\mathrm{mm}$ mesh size nylon bags were used to quantify the decomposition rate of fine roots. Fine root samples were air dried at room temperate to constant mass. Each bag was filled in a known amount of air-dried fine roots $(5 \mathrm{~g})$. Sub-samples of fine roots were retained for the determination of moisture content and initial chemical composition. For each size class and tree species, 60 bags were prepared and incubated in the soil at a depth of $10 \mathrm{~cm}$ in May 1999; 6 bags were retrieved randomly after 30, 60, 90, 150, $210,270,360,450$, and $540 \mathrm{~d}$ of sample placement, and transported to the laboratory. The adherent soil and plant detritus were excluded, and the samples were then oven-dried at $60{ }^{\circ} \mathrm{C}$ to constant weight for the determination of remaining weight. Sub-samples of each date were retained for the analysis of their chemical composition.

\subsection{Chemical analyses}

All sub-samples were oven-dried, ground and passed through a $0.25-\mathrm{mm}$ mesh screen. For the determination of $\mathrm{C}$, the root samples were digested in a $\mathrm{K}_{2} \mathrm{Cr}_{2} \mathrm{O}_{7}-\mathrm{H}_{2} \mathrm{SO}_{4}$ solution (1:1) by oil-bath (175 \pm $5{ }^{\circ} \mathrm{C}$ ) and then the $\mathrm{C}$ concentration was determined by titration [10]. For determination of $\mathrm{N}$ and $\mathrm{P}$, the samples were digested in a solution of $\mathrm{H}_{2} \mathrm{SO}_{4}-\mathrm{HClO}_{4}(10: 1)$, and then $\mathrm{N}$ concentration was determined by the micro-Kjeldahl technique, and $\mathrm{P}$ concentration was determined colorimetrically by forming chloro-phosphoric molybdate (blue colour) [10]. TNC were measured using a takadiastase digestion of non-extracted subsamples followed by a titrametric determination of reducing power [20]. Solutes, acid soluble fiber (largely holocellulose), acid insoluble fiber (largely lignin and suberin) and lignin were determined by proximate chemical analysis [31]. All results are presented on an ash-free dry matter basis.

\subsection{Statistical analysis}

Statistical analyses were performed with the Statistical Program for Social Science (SPSS) software for analysis of variance (ANOVA), and Newman-Keuls tests for comparisons of mean values (significance for $P<0.05$ ). The model for constant potential weight loss is represented by the following equation: $x / x_{0}=\exp (-k t)$, where $x$ is the weight remaining at time $t, x_{0}$ is the initial weight, the constant $k$ is the decomposion coefficient, and $t$ is the time. Linear regressions between mass loss as dependent variable, lignin, $\mathrm{N}, \mathrm{P}$, $\mathrm{TNC}$, lignin/ $\mathrm{N}$ ratio and lignin/P ratio as independent variables were performed for three successive periods as presented below and the whole study period.

\section{RESULTS}

\subsection{Dry weight loss}

Fine roots decomposed in a three-phase manner in a 540-d period: for the Chinese fir, an initial relatively low rate of decay up to $90 \mathrm{~d}$, was followed by a period of rapid weight loss until $270 \mathrm{~d}$, and then by a phase of low decay rate; and for the Tsoong's tree, a rapid weight loss period up to $60 \mathrm{~d}$ followed by a relatively rapid weight loss period between 60-360 d, and a slow rate of decay period from $360 \mathrm{~d}$ (Fig. 1).

Percentages of mass lost after 1 year of decomposition from litter bags ranged from $58.5 \%$ to $63.3 \%$ for the Chinese fir and $68.8 \%$ to $78.2 \%$ for the Tsoong's tree (Tab. I). Fine roots with a thicker diameter had a lower rate of mass loss $(P<0.05)$. The 

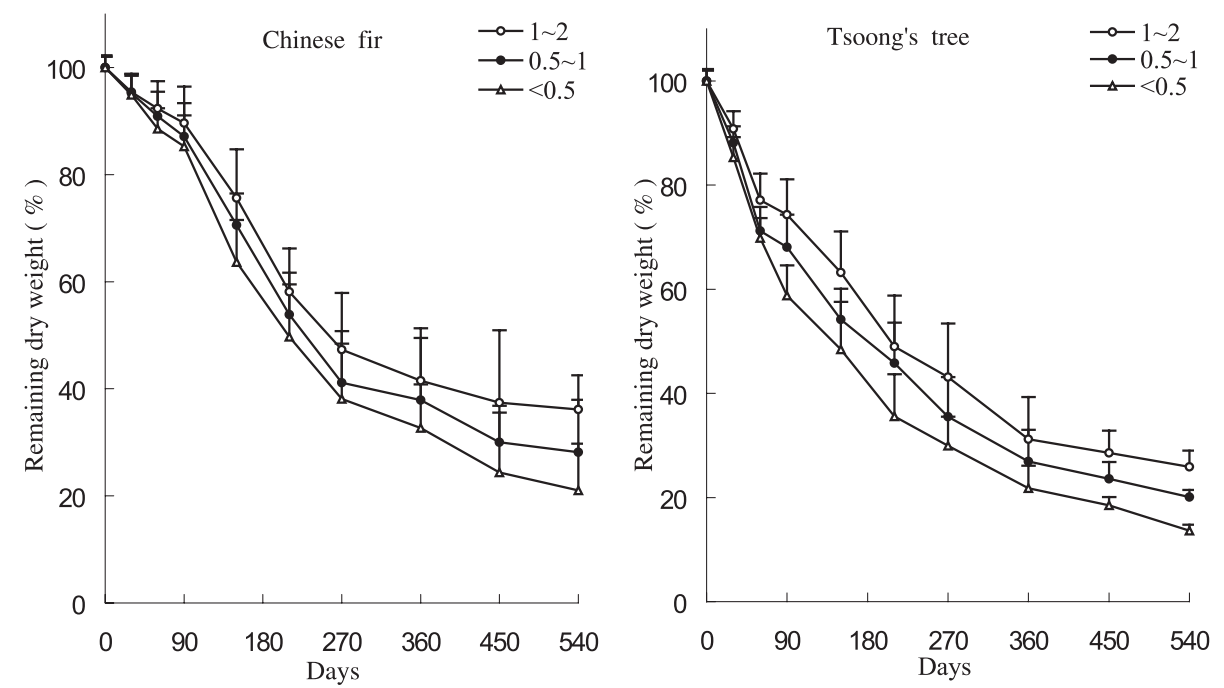

Figure 1. Percentage of dry-matter remaining over time in decomposing fine roots of Chinese fir and Tsoong's tree. Bars indicate standard error.

Table I. Weight loss rate and decay constant $(\mathrm{k})$ of fine roots after one year decay. Values followed by different letters on the same column indicate significant differences at $P<0.05$.

\begin{tabular}{|c|c|c|c|c|c|c|c|c|}
\hline \multirow[t]{2}{*}{ Tree species } & \multirow{2}{*}{$\begin{array}{l}\text { Diameter } \\
\text { class } \\
(\mathrm{mm})\end{array}$} & \multicolumn{2}{|c|}{ Decay constant (k) } & \multirow{2}{*}{$\begin{array}{c}\text { Correlation } \\
\text { coefficient } \\
(r)\end{array}$} & \multirow{2}{*}{$\begin{array}{c}\text { Expected rate } \\
\text { of weight loss } \\
(\%)\end{array}$} & \multirow{2}{*}{$\begin{array}{c}\text { Observed rate } \\
\text { of weight loss } \\
(\%)\end{array}$} & \multirow{2}{*}{$\begin{array}{c}\text { Mean half-time } \\
\text { (day) }\end{array}$} & \multirow{2}{*}{$\begin{array}{c}\text { Time of total } \\
\text { decomposition } \\
\text { (day) }\end{array}$} \\
\hline & & day-based & year-based & & & & & \\
\hline \multirow[t]{3}{*}{ Tsoong's tree } & $1-2$ & 0.0028 & 1.01 & -0.9616 & 63.5 & $68.8 \mathrm{a}$ & 248 & 1070 \\
\hline & $0.5-1$ & 0.0033 & 1.19 & -0.9629 & 69.5 & $73.1 \mathrm{~b}$ & 210 & 908 \\
\hline & $<0.5$ & 0.0040 & 1.44 & -0.9553 & 76.3 & $78.2 \mathrm{c}$ & 173 & 749 \\
\hline \multirow[t]{3}{*}{ Chinese fir } & $1-2$ & 0.0022 & 0.79 & -0.9333 & 54.7 & $58.5 \mathrm{a}$ & 315 & 1362 \\
\hline & $0.5-1$ & 0.0026 & 0.94 & -0.9298 & 60.8 & $62.1 \mathrm{~b}$ & 267 & 1152 \\
\hline & $<0.5$ & 0.0031 & 1.12 & -0.9431 & 67.2 & $63.3 b$ & 224 & 966 \\
\hline
\end{tabular}

negative exponential decay model showed a good fit for the decay pattern of the fine roots of both species and regressions were highly significant $\left(r^{2}>0.9, P<0.05\right)$ (Tab. I). The time of total decomposition (95\% decay) was 749-1 $070 \mathrm{~d}$ for Tsoong's tree and 966-1 $362 \mathrm{~d}$ for the Chinese fir.

\subsection{Nutrient release}

Changes in $\mathrm{N}$ and $\mathrm{P}$ concentrations in fine roots during decomposition differed between species and diameters: for Chinese fir, $\mathrm{N}$ concentrations increased followed by a decline in all size classes; and the duration of increase ranges from $210 \mathrm{~d}$ for fine roots $<0.5 \mathrm{~mm}$ to $360 \mathrm{~d}$ for fine roots $1-2 \mathrm{~mm}$ (Fig. 2). For Tsoong's tree, $\mathrm{N}$ concentration increased slightly initially in fine roots $0.5-1 \mathrm{~mm}$ and $1-2 \mathrm{~mm}$. P concentrations in fine roots of Tsoong's tree showed consistent decrease, while they remained stable or relatively increased slightly in those of the Chinese fir (Fig. 2). Generally, both C and TNC concentrations decreased, and concentrations of lignin relatively increased during fine root decomposition for the two tree species (Tab. II).

The absolute amounts of $\mathrm{N}$ increased initially in fine roots of the Chinese fir with a low magnitude and a short duration (Fig. 3). In contrast, fine roots of the Tsoong's tree were releasing $\mathrm{N}$ from the start of the experiment. The absolute amounts of $\mathrm{P}$ decreased in fine roots of the two tree species during decomposition (Fig. 3). Fine roots of Tsoong's tree released $\mathrm{N}$ and $\mathrm{P}$ at a faster rate than those of Chinese fir $(P<$ $0.05)$. After $540 \mathrm{~d}$, the rates of $\mathrm{N}$ and $\mathrm{P}$ release relative to dry mass loss can be arranged in the sequence of: dry mass $>P>$ $\mathrm{N}$ for the Chinese fir; and $P>$ dry mass $=\mathrm{N}$ for the Tsoong's tree (Figs. 1 and 3). Our estimates of nutrient release from fine roots can also be combined with the exponential model to describe changes in absolute amounts of nutrients during the decomposition $\left(r^{2}>0.9, P<0.05\right)$, with the exception of $\mathrm{N}$ in all size classes of the Chinese fir.

\section{DISCUSSION}

\subsection{Dry weight loss}

Mass losses from litter bags during the study period appeared in three consecutive phases as often reported in many studies in which the root decomposed at least two phases $[6,20]$. Early losses of mass from fresh root litter may be due to leaching and microbial or root respiration of readily soluble compounds [20]. During the initial decay stage, the losses of 

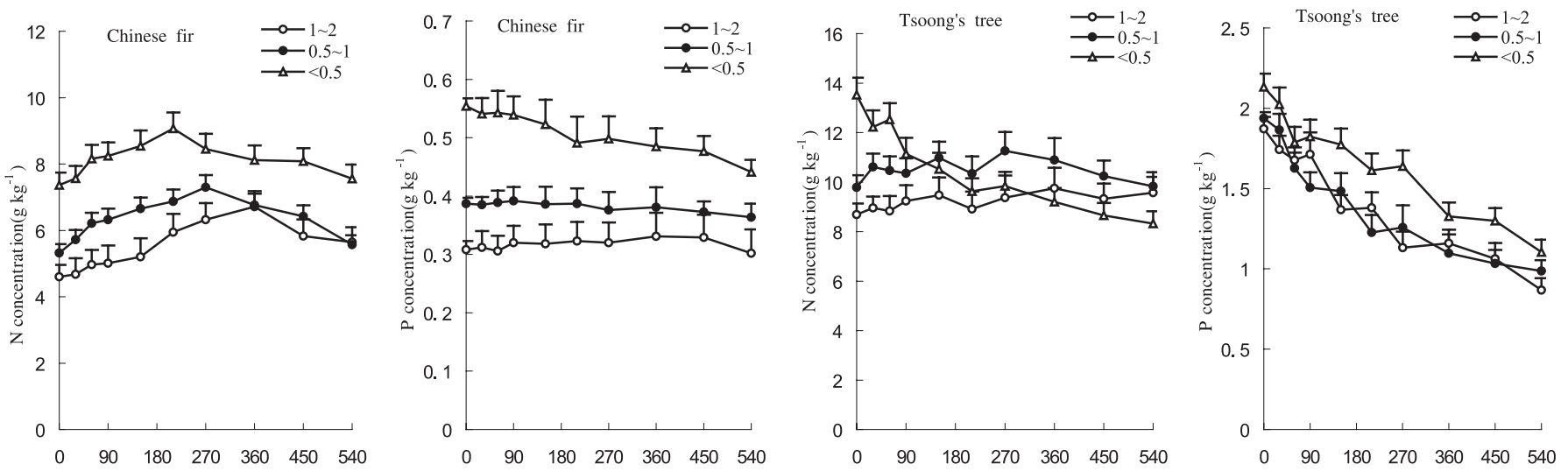

Days

Figure 2. Changes in $\mathrm{N}$ and $\mathrm{P}$ concentrations over time in decomposing fine roots of Chinese fir and Tsoong's tree. Bars indicate standard error.

soluble compounds contributed half or more of the initial dry mass losses (Tab. II). The next phase of weight loss was presumably due to active consumption of readily available energy sources by microbes (mainly holocellulose). Also, lignin (acid-insoluble) is degraded in this phase with a lower extent relative to acid-solubles (Tab. II). A remarkable reduction in the decay rate during the third phase might be related to the relatively higher percentage of recalcitrant fractions like lignin (acid-insoluble) in the decaying root tissue (Tab. II). These materials were known to control decomposition rate through their own resistance to enzymatic attack and by physically interfering with the decay of other chemical fractions of the cell wall $[5,9]$.

Fine roots with a smaller diameter had a higher rate of mass loss in this study (Tab. I), which agrees with the common findings in other studies $[5,9,27]$, but differs from the observation of McClaugherty et al. (1984) who found slower root decomposition for small roots [20]. The decrease in the rate of decomposition with increasing root diameter as observed in the present study might be due to the initial $\mathrm{N}$ concentration that was related to root diameter (Tab. I). Smaller roots having higher $\mathrm{N}$ concentration decomposed at somewhat faster rate compared to thicker roots. However, it seems that there is no consistent pattern between the rate of root decomposition and $\mathrm{N}$ concentration [9]. Camiré et al. [9] explained that when roots have a high $\mathrm{N}$ concentration, their rate of decomposition may be lowest in roots with the highest initial $\mathrm{N}$ concentration, and when low in $\mathrm{N}$, the rate of decomposition may be highest in the roots with the highest initial $\mathrm{N}$ concentration [9]. In view of the significantly higher root $\mathrm{N}$ concentrations in the Chinese fir and the Tsoong's tree as compared to other studies, our results did not hold for the hypothesis of Camiré et al. [9].

The external factors, including temperature, water content, and chemical characteristics of the soil may also control the decay rate of fine roots [22]. Similar mass losses have been reported for fine roots of the Chinese fir $(61.3 \%)$ after 1 year of decomposition in Huitong north of our research site [15], while much lower values of $12 \%$ to $25 \%$ were obtained for red pine, Scots pine, Douglas fir, and mixed hardwood in temperate zones [4, 11, 19]. The values of annual decay constant (k, year-based) for the fine roots of the Chinese fir and the Tsoong's tree (Tab. I) fall in the range of the values reported for the forests of the world (0.03-1.74) [2, 8, 11, 15, 23, 26, 29 ], and were comparable with the values for the subtropical forest ecosystems $(0.6-1.74)$ [2, 8, 15].

Although coarser mesh litter bags $(0.5 \mathrm{~mm})$ were used in the experiments of the aboveground litter decomposition, which may have some effects on decaying rate, the rates of fine root decomposition are in the vicinity of those for the corresponding above-ground tissue $(56.31 \%$ for the needles of Chinese fir and $74.54 \%$ for the leaves of Tsoong's tree after 1 year of decay) in the same study [33]. This, however, was not true in the studies of McClaugherty et al. [19] and Usman et al. [27], where the mass loss rates of aboveground litters were much higher than those in fine roots $[19,27]$.

\subsection{Nutrient release}

The initial increase of $\mathrm{N}$ concentration in fine roots of the Chinese fir was largely due to microbial immobilization (Fig. 2). The tendency for $\mathrm{P}$ concentration to decrease or remain relatively constant indicated that there was little $\mathrm{P}$ immobilization (Fig. 2). The differences in changes of $\mathrm{N}$ and $\mathrm{P}$ concentrations between fine roots of the two species might be due to the different $\mathrm{N}$ and $\mathrm{P}$ availability for microorganisms in the fine roots. A bi-phasic pattern for nutrient release from decomposing fine roots of the two species (Fig. 3), characterized by an initial rapid and a subsequent slow release phase, was different from the generalized tri-phasic model proposed by Berg and Staaf [4]. Compared with other studies, there only occurred for $\mathrm{N}$ in the fine roots of Chinese fir an initial microbiological immobilization with a low magnitude and a short duration, and release of $\mathrm{P}$ began from the outset for both species without a period of net immobilization (Fig. 3), indicating that the $\mathrm{N}$ and $\mathrm{P}$ availability for microorganisms in the site were relatively high $[2,5,8]$. Of the initial amount of $\mathrm{P}$ in fine roots of Tsoong's tree, 30.9-41.5\% was lost from decomposing root litter during the first 60 days compared with a weight loss of 22.9-30.2\% (Figs. 1 and 3); this indicated initial leaching loss of P. It has also been emphasized that the importance 
Table II. The chemical composition and weight loss rates during the three decay phases. Values within parentheses indicate standard errors.

\begin{tabular}{|c|c|c|c|c|c|c|c|c|c|c|c|}
\hline \multirow{2}{*}{$\begin{array}{l}\text { Tree } \\
\text { species }\end{array}$} & \multirow{2}{*}{$\begin{array}{c}\text { Root } \\
\text { diameter } \\
(\mathrm{mm})\end{array}$} & \multirow[t]{2}{*}{ Periods } & \multicolumn{5}{|c|}{ Concentration } & \multicolumn{4}{|c|}{ Percentage of weight loss (\%) } \\
\hline & & & $\begin{array}{c}\mathrm{N} \\
\left(\mathrm{g} \cdot \mathrm{kg}^{-1}\right)\end{array}$ & $\begin{array}{c}\mathrm{P} \\
\left(\mathrm{g} \cdot \mathrm{kg}^{-1}\right)\end{array}$ & $\begin{array}{l}\mathrm{C} \\
(\%)\end{array}$ & $\begin{array}{c}\text { Lignin } \\
(\%)\end{array}$ & $\begin{array}{c}\mathrm{TNC} \\
(\%)\end{array}$ & Dry-mass & Solute & $\begin{array}{c}\text { Acid- } \\
\text { soluble }\end{array}$ & $\begin{array}{c}\text { Acid- } \\
\text { insoluble }\end{array}$ \\
\hline \multirow[t]{18}{*}{ Chinese fir } & \multirow[t]{6}{*}{$<0.5$} & $0-90$ & 7.37 & 0.55 & 43.6 & 32.8 & 8.1 & 14.8 & 7.07 & 4.66 & 3.08 \\
\hline & & & $(0.37)$ & $(0.01)$ & $(2.22)$ & $(1.3)$ & $(0.3)$ & (1.5) & $(0.7)$ & $(0.4)$ & $(0.3)$ \\
\hline & & $90-270$ & 8.24 & 0.54 & 44.52 & 35.4 & 4.9 & 47.13 & 5.76 & 26.91 & 14.46 \\
\hline & & & $(0.41)$ & $(0.03)$ & (2.4) & $(0.9)$ & $(0.2)$ & (4.6) & $(0.5)$ & $(2.5)$ & $(1.5)$ \\
\hline & & $270-540$ & 8.45 & 0.50 & 42.47 & 39.9 & 3.9 & 17.09 & 1.96 & 8.84 & 6.29 \\
\hline & & & $(0.46)$ & $(0.04)$ & $(2.25)$ & $(1.1)$ & $(0.2)$ & $(3.0)$ & $(0.3)$ & $(1.4)$ & $(1.1)$ \\
\hline & \multirow[t]{6}{*}{$0.5-1$} & 0-90 & 5.32 & 0.39 & 49.45 & 33.5 & 7.8 & 12.9 & 6.3 & 3.7 & 2.9 \\
\hline & & & $(0.27)$ & $(0.01)$ & $(2.49)$ & $(0.8)$ & $(0.3)$ & $(1.2)$ & $(0.5)$ & $(0.3)$ & $(0.3)$ \\
\hline & & $90-270$ & 6.32 & 0.39 & 50.94 & 35.1 & 5.4 & 45.97 & 5.54 & 26.85 & 13.58 \\
\hline & & & $(0.33)$ & $(0.02)$ & $(2.72)$ & $(1.3)$ & $(0.2)$ & (5.3) & $(0.6)$ & $(2.9)$ & (1.6) \\
\hline & & $270-540$ & 7.30 & 0.38 & 45.4 & 40.7 & 4.8 & 13 & 1.53 & 6.73 & 4.75 \\
\hline & & & $(0.37)$ & $(0.03)$ & (2.6) & $(1.5)$ & $(0.2)$ & (3.3) & $(0.4)$ & (1.6) & $(1.2)$ \\
\hline & \multirow[t]{6}{*}{$1-2$} & $0-90$ & 4.60 & 0.31 & 55.2 & 35.5 & 6.9 & 10.4 & 5.7 & 2.3 & 2.4 \\
\hline & & & $(0.36)$ & $(0.02)$ & $(2.78)$ & $(1.2)$ & $(0.4)$ & $(0.8)$ & $(0.4)$ & $(0.2)$ & $(0.2)$ \\
\hline & & $90-270$ & 5.01 & 0.32 & 50.87 & 36.9 & 4.7 & 42.29 & 5.1 & 23.59 & 13.6 \\
\hline & & & $(0.53)$ & $(0.03)$ & $(2.82)$ & $(1.4)$ & $(0.3)$ & $(4.7)$ & $(0.5)$ & $(2.4)$ & (1.5) \\
\hline & & $270-540$ & 6.32 & 0.32 & 45.33 & 41.2 & 3.8 & 11.19 & 1.11 & 5.91 & 4.17 \\
\hline & & & $(0.51)$ & $(0.04)$ & $(2.58)$ & (1.6) & $(0.3)$ & (3.3) & $(0.3)$ & (1.6) & (1.3) \\
\hline \multirow[t]{18}{*}{ Tsoong's tree } & \multirow[t]{6}{*}{$<0.5$} & $0-60$ & 13.52 & 2.13 & 43.3 & 18.1 & 14.9 & 30.2 & 18.9 & 9.11 & 2.19 \\
\hline & & & $(0.70)$ & $(0.08)$ & $(2.17)$ & $(0.7)$ & $(0.6)$ & $(2.2)$ & $(1.3)$ & $(0.6)$ & $(0.2)$ \\
\hline & & $60-360$ & 12.53 & 1.79 & 45.18 & 20.3 & 8.6 & 48.04 & 6.32 & 32.03 & 9.7 \\
\hline & & & $(0.65)$ & $(0.11)$ & $(2.28)$ & $(0.7)$ & $(0.4)$ & (7.4) & $(0.9)$ & $(4.6)$ & (1.5) \\
\hline & & $360-540$ & 9.20 & 1.33 & 34.52 & 23.3 & 8.2 & 8.2 & 3.94 & 2.45 & 1.81 \\
\hline & & & $(0.58)$ & $(0.10)$ & (1.86) & $(0.8)$ & $(0.3)$ & (1.1) & $(0.5)$ & $(0.3)$ & $(0.3)$ \\
\hline & \multirow[t]{6}{*}{$0.5-1$} & $0-60$ & 9.78 & 1.94 & 45.18 & 21.6 & 13.7 & 28.8 & 16.61 & 10.1 & 2.09 \\
\hline & & & $(0.49)$ & $(0.04)$ & $(2.27)$ & $(0.7)$ & $(0.5)$ & (2.3) & $(1.2)$ & $(0.8)$ & $(0.2)$ \\
\hline & & $60-36$ & 10.47 & 1.63 & 41.52 & 23.1 & 8.3 & 44.31 & 6.5 & 27.52 & 10.29 \\
\hline & & & $(0.60)$ & $(0.10)$ & (2.1) & $(0.8)$ & $(0.4)$ & (7.3) & $(1.0)$ & $(4.3)$ & $(1.8)$ \\
\hline & & $360-540$ & 10.89 & 1.10 & 34.1 & 26.3 & 7.6 & 7.8 & 2.58 & 3.33 & 1.89 \\
\hline & & & $(0.76)$ & $(0.14)$ & $(1.97)$ & $(0.9)$ & $(0.3)$ & (1.8) & $(0.5)$ & $(0.7)$ & $(0.4)$ \\
\hline & \multirow[t]{6}{*}{$1-2$} & $0-60$ & 8.69 & 1.87 & 49.2 & 24.8 & 12.8 & 22.9 & 11.77 & 9.21 & 1.92 \\
\hline & & & $(0.44)$ & $(0.08)$ & $(2.47)$ & $(0.8)$ & $(0.5)$ & (1.4) & $(0.7)$ & $(0.5)$ & $(0.1)$ \\
\hline & & $60-360$ & 8.83 & 1.68 & 36.84 & 26.8 & 8.4 & 32 & 6.25 & 15.6 & 10.15 \\
\hline & & & $(0.64)$ & $(0.14)$ & $(1.86)$ & $(1.0)$ & $(0.3)$ & (7.1) & $(1.3)$ & $(3.2)$ & (2.3) \\
\hline & & $360-540$ & 9.75 & 1.16 & 35.15 & 28.2 & 8.1 & 6.31 & 2.31 & 1.96 & 2.04 \\
\hline & & & $(0.89)$ & $(0.10)$ & (2.8) & $(1.2)$ & $(0.3)$ & (1.9) & $(0.6)$ & $(0.5)$ & $(0.6)$ \\
\hline
\end{tabular}

of the initial ratios of $\mathrm{C}$ to nutrients in determining nutrient mineralization [29]. In this study the values of $\mathrm{C} / \mathrm{N}$ were 59120 for roots of the Chinese fir and 32-57 for roots of the Tsoong's tree, and the corresponding values of C/P were 793 1781 and 203-263, respectively (Tab. II). The higher release rate of both $\mathrm{N}$ and $\mathrm{P}$ in fine roots of Tsoong's tree could be contributed to the lower initial values of $\mathrm{C} / \mathrm{N}$ and $\mathrm{C} / \mathrm{P}$.

\subsection{Control of decomposition}

In most studies of litter decomposition, the decay rates were often related to litter quality of a pool of different species that included both intraspecific and interspecific differences $[5,6$, $9,24,28]$. In this study, roots of different diameter classes of the same species were pooled together to create a range of substance qualities, thus, the interspecific interferences were excluded and only the intraspecific difference were included in the predictions of the mass loss rate (Tab. III).

The mass loss rate was found to have only significant correlation with initial TNC for both species in the first phase of decay, indicating that decomposition rates were regulated by TNC (Tab. III). The significant correlations between mass loss and $\mathrm{N}$ concentration, and lignin/ $\mathrm{N}$ ratio, and the lack of significant correlations between mass loss and lignin/P ratio for the Chinese fir in the second decomposition phase indicated that mass losses for the Chinese fir roots were regulated by $\mathrm{N}$ concentration, and that $\mathrm{N}$ was relatively less available than $\mathrm{P}$ for microorganisms during this decay stage (Tab. III). During 

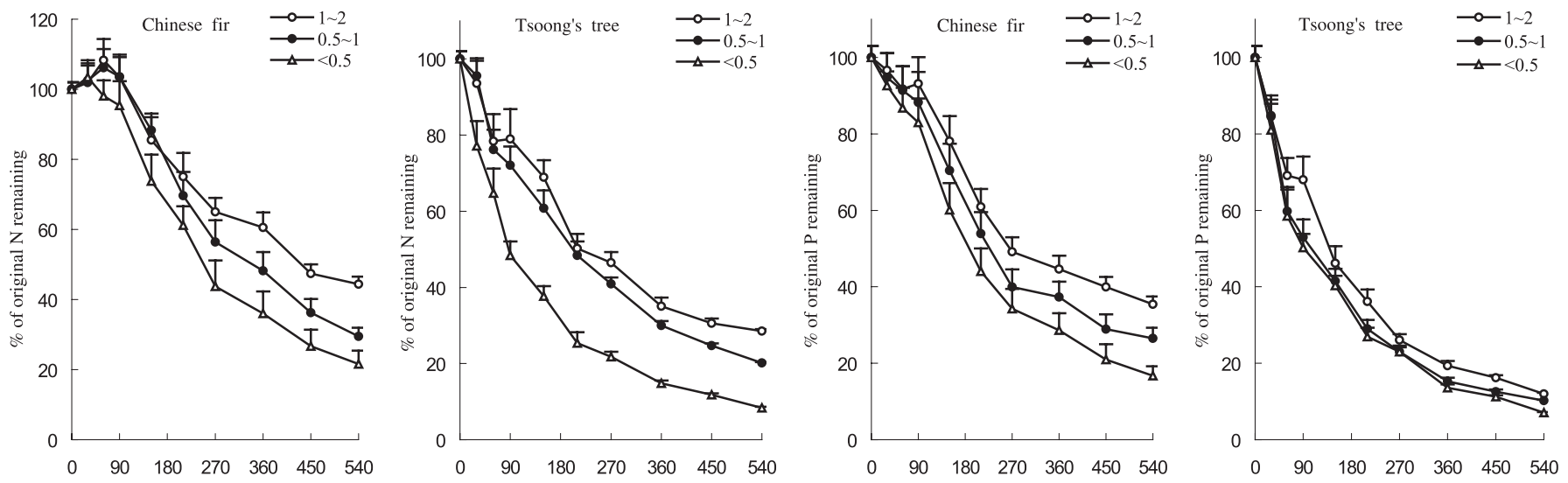

Days

Figure 3. Percentage of nutrient remaining over time in decomposing fine roots of Chinese fir and Tsoong's tree. Bars indicate standard error.

Table III. Correlations between rates of dry matter loss with $\% \mathrm{~N}, \% \mathrm{P}, \%$ lignin, $\% \mathrm{TNC}$, and the ratios of $\%$ lignin/\% N and $\%$ lignin/\% P during the three decay phases. Probabilities of observing larger correlations are given in parentheses $(n=18 ; * P<0.05 ; * * P<0.01)$.

\begin{tabular}{|c|c|c|c|c|c|c|c|}
\hline Tree species & Periods & $\mathrm{N}$ & $\mathrm{P}$ & Lignin & $\mathrm{TNC}$ & Lignin/N & Lignin/P \\
\hline \multirow[t]{8}{*}{ Chinese fir } & 0-90 & 0.746 & 0.602 & -0.657 & $0.905^{*}$ & -0.703 & -0.614 \\
\hline & & $(0.084)$ & $(0.234)$ & $(0.103)$ & $(0.011)$ & $(0.091)$ & $(0.173)$ \\
\hline & $90-270$ & $0.92 *$ & 0.679 & $-0.856^{*}$ & 0.692 & $-0.91 *$ & -0.703 \\
\hline & & $(0.026)$ & $(0.111)$ & $(0.030)$ & $(0.115)$ & $(0.015)$ & $(0.094)$ \\
\hline & $270-540$ & 0.73 & 0.891 & -0.856 & -0.514 & 0.715 & $0.931 *$ \\
\hline & & $(0.102)$ & $(0.026)$ & $(0.033)$ & $(0.211)$ & $(0.21)$ & $(0.011)$ \\
\hline & $0-540$ & $0.806^{*}$ & 0.790 & $-0.807 *$ & 0.603 & $-0.915 * *$ & $-0.842^{*}$ \\
\hline & & $(0.048)$ & $(0.076)$ & $(0.043)$ & $(0.382)$ & $(0.009)$ & $(0.031)$ \\
\hline \multirow[t]{8}{*}{ Tsoong's tree } & $0-60$ & 0.801 & 0.644 & -0.695 & $0.93 *$ & -0.69 & -0.635 \\
\hline & & $(0.126)$ & $(0.252)$ & $(0.127)$ & $(0.013)$ & $(0.141)$ & $(0.151)$ \\
\hline & $60-360$ & 0.719 & 0.682 & $-0.89 *$ & 0.72 & -0.763 & -0.617 \\
\hline & & $(0.081)$ & $(0.207)$ & $(0.031)$ & $(0.133)$ & $(0.073)$ & $(0.242)$ \\
\hline & $360-540$ & -0.687 & 0.575 & $0.873^{*}$ & 0.367 & 0.756 & 0.693 \\
\hline & & $(0.143)$ & $(0.302)$ & $(0.035)$ & $(0.543)$ & $(0.161)$ & $(0.178)$ \\
\hline & $0-540$ & 0.701 & 0.568 & $-0.76^{*}$ & 0.71 & -0.52 & -0.46 \\
\hline & & $(0.139)$ & $(0.260)$ & $(0.044)$ & $(0.25)$ & $(0.34)$ & $(0.58)$ \\
\hline
\end{tabular}

the second phase, only the correlation between mass loss rate and \% lignin were found significant for roots of the Tsoong's tree (Tab. III). Our results are consistent with the earlier works which showed that as lignin concentrations increase during litter decomposition the decay rates are suppressed [14, 21], and the decomposition rate of remaining litter would thus be ruled by the lignin degradation rate as the cellulose in the remaining parts would be shielded by lignin [7].

During the last phase, significant correlation between mass loss and lignin/P ratio and no significant correlation between mass loss and lignin/ $\mathrm{N}$ ratio were found for the Chinese fir roots (Tab. III). It seems to indicate that mass losses became increasingly dependent on the lignin/P ratio. This is consistent with the hypothesis given by Gallardo and Merino [12] that difference in the biochemistry of $\mathrm{N}$ as opposed to $\mathrm{P}$ may be important in order to explain the availability of these nutrients to decomposers and the role of $\mathrm{N}$ and $\mathrm{P}$ in determining the litter mass loss [12]. Detrital $\mathrm{N}$ is mostly carbon-bonded (C-N) and often in structural or complexed forms, while detrital $\mathrm{P}$ is mostly $\mathrm{PO}_{4}{ }^{3-}$-aminon hydrolyzed by esterextracellular phosphatases that cleave the ester phosphate bond. In contrast, multiple enzyme systems are involved in the breakdown of structural or phenolic $\mathrm{N}$-containing organic compounds before any $\mathrm{N}$ can be released into available forms. Consequently, $\mathrm{N}$ may be relatively less available than $\mathrm{P}$ in initial litter. As decomposition proceeds, $\mathrm{P}$ may become less available than $\mathrm{N}$ for decomposers and, at this stage, $\mathrm{P}$ content may be the main nutrient controlling the decomposition process [12]. 
For roots of the Tsoong's tree during the last decomposition phase, mass losses were found significantly and positively correlated with \% lignin (Tab. III). Our results seem to confirm the findings of Berg (1986) that high initial $\mathrm{N}$ can be associated with low rate of root decomposition and low initial levels of lignin could have resulted in lower rates of decomposition after the initial rapid mass loss [6]. The control of mass loss by lignin at the condition of high $\mathrm{N}$ concentration in the late stage may result from the lignin-nitrogen interactions (Tab. III). Berg et al. (1984) found that the N-lignin derivative compounds, which are more resistant substances such as humic substance, are formed in $\mathrm{N}$-rich roots [5]. Thus, the higher $\mathrm{N}$ content, the more lignin was combined into the high-resistant secondary compounds; and the increase in relative importance of lignin as a predictor of mass loss in the later phase may indicate that $\mathrm{C}$ is increasingly limiting microbial biomass in litter. It seemed that high $\mathrm{N}$ concentrations enhanced the decomposition of the water-soluble compounds and non-lignified cellulose and repressed the formation of lignolytic enzymes.

In this study, the chemical constituents $(\mathrm{N}, \mathrm{P}$, lignin and TNC) affect decomposition of fine roots differently during different decay phases and between litter species (Tab. III). TNC contribute largely to the initial mass loss through leaching. During the second phase of decomposition, \% lignin and \% $\mathrm{N}$ would affect root decomposition greatly (Tab. III). $\mathrm{N}$ is likely to be responsible for determining the amount of microbial biomass in litter, which in turn determines the amount of new recalcitrant material formed in litter, and the mineralization of P. Meanwhile lignin, known as recalcitrant material, keeps the cell wall from degradation. If roots are low in $\mathrm{N}$ or high in lignin such as for the Chinese fir in this study, the rate of root decomposition during this phase may be regulated by both the $\% \mathrm{~N}$ and \% lignin. As the release of $\mathrm{P}$ and the consumption of readily available energy sources proceeds, litter $\mathrm{P}$ instead of litter $\mathrm{N}$ becomes less available for microorganisms [12], and lignin becomes more important as an energy source for microorganisms. If the fine roots are low in $\mathrm{P}$ (as in the Chinese fir) or low in lignin (as in the Tsoong's tree), the decay rate then would be regulated by $\mathrm{P}$ or lignin (Tab. III).

Even though single chemical characteristics of roots may have a limited potential for predicting the rate of decomposition, they could be reliable predictors for a limited range [20]. During the study period of decay (540 d), N concentration, lignin content, ratio of lignin/ $\mathrm{N}$ and ratio of lignin/P of the initial material were the best predictors of mass loss for roots of the Chinese fir; and initial lignin concentration was the best predictor of decomposition rate for roots of the Tsoong's tree (Tab. III). These results are in agreement with the findings of other authors who found the lignin, $\mathrm{N}$ and the lignin/nutrient ratio to be the best predictors of litter decomposition rate in a wide range of ecosystems $[12,20]$.

\section{CONCLUSION}

Decomposition of fine roots is an important process of nutrient releasing and intimately linked to soil fertility. In order to give an overall evaluation of the potential of mixed forests of Chinese fir and broadleaved trees to preserve longterm site productivity, a mixed forest of Chinese fir and
Tsoong's tree was chosen to study the decomposition dynamic of fine roots. The result showed that the decomposition of fine roots of both Chinese fir and Tsoong's tree appeared in a threephase manner. After 1 year of decomposition, 58.5-63.3\% and $68.8-78.2 \%$ of dry mass were lost for Chinese fir and Tsoong's tree, respectively. Mass loss of fine roots decreased with increasing root diameter. Pattern of change of $\mathrm{N}$ and $\mathrm{P}$ concentrations differed with diameter and tree species. An initial net immobilization of $\mathrm{N}$ occurred in fine roots of Chinese fir. Release of $\mathrm{P}$ was found from the outset of experiment for both species. The successive control of decomposition rate by the TNC, lignin (or N) and P (or lignin) was found during the different decomposition stage.

Acknowledgements: This work was financed by the National Natural Science Foundation of China (30170770), the Post-doctoral Research Foundation of China, and the Supporting Program for University Elitists by the Ministry of Education of China.

\section{REFERENCES}

[1] Aber J.D., Melillo J.M., Fine root turnover in forest ecosystems in relation to quality and form of nitrogen availability: a comparison of two methods, Oecologia 66 (1985) 317-321.

[2] Arunachalam A., Pandey H.N., Tripathi R.S., Maithani K., Fine root decomposition and nutrient mineralization patterns in a subtropical humid forest following tree cutting, For. Ecol. Manage. 86 (1996) 141-150.

[3] Augusto L., Ranger J., Binkley D., Rothe A., Impact of several common tree species of European temperate forests on soil fertility, Ann. For. Sci. 59 (2002) 233-253.

[4] Berg B., Staaf H., Decomposition rate and chemical changes in decomposing needle litter of Scots pine. II. Influence of chemical composition -in structure and function of northern coniferous forests- an ecosystem study, Ecol. Bull. 32 (1981) 373-390.

[5] Berg B., Decomposition of root litter and some factors regulating the process. Long-term root litter decomposition in a Scots pine forest, Soil Biol. Biochem. 16 (1984) 609-617.

[6] Berg B., Nutrient release from litter and humus in coniferous forest soils-A mini review, Scand. J. For. Res. 1 (1986) 359-369.

[7] Berg B., Litter decomposition and organic matter turnover in northern forest soils, For. Ecol. Manage. 133 (2000) 13-22.

[8] Bloomfield J., Vogt K.A., Vogt D.J., Decay rate and substrate quality of fine roots and foliage of two tropical tree species in the Luquillo Experimental Forest, Puerto Rico, Plant Soil 150 (1993) 233-245.

[9] Camiré C., Côté B., Brulotte S., Decomposition of roots of black alder and hybrid poplar in short-rotation plantings: Nitrogen and lignin control, Plant Soil 138 (1991) 123-132.

[10] Department of National Forestry, The compilation of forestry criteria (III), Chinese Forestry Publishing House, Beijing, 2000 (in Chinese).

[11] Fogel R., Hunt G., Fungal and arboreal biomass in a western Oregon Douglar-fir ecosystem. Distribution patterns and turnover, Can. J. For. Res. 9 (1979) 245-256.

[12] Gallardo A., Merino J., Control of leaf litter decomposition rate in a Mediterranean shrubland as indicated by $\mathrm{N}, \mathrm{P}$ and lignin concentrations. Pedobiologia 43 (1999) 64-72.

[13] Grier C.C., Vogt K.A., Keys M.R., Edmonds R.L., Biomass distribution and above and below ground production in a young and 
mature Abies amabilis zone ecosystems of the Washington cascades, Can. J. For. Res. 11 (1981) 155-167.

[14] Horner J.D., Gosz J.R., Cates R.G., The role of carbon-based plant secondary metabolites in decomposition in terrestrial ecosystems, Am. Nat. 132 (1988) 869-883.

[15] Liao L.P., Chen C.Y., Zhang J.W., Turnover of fine roots in pure and mixed Cunninghamia lanceolata and Michelia macclure forests, Chin. J. Appl. Ecol. 6 (1995) 7-10 (in Chinese with English abstract).

[16] Liao L.P., Deng S.J., Yu X.J., Han S.J., Growth, distribution and exudation of fine roots of Chinese, fir trees grown in continuously cropped plantations, Acta. Ecol. Sin. 21 (2001) 569-573 (in Chinese with English abstract)

[17] Liao L.P., Wang S.L., Gao H., Foliar litter decomposition of Chinese fir and main broad-leaved plantation species in subtropics, Chin. J. Appl. Ecol. 11 (2000) 141-145 (in Chinese with English abstract).

[18] Lin R.Y., Chen Y.X., Chen G.S., Yang Y.S., Primary study on soil fertility in mixed forest of Cunninghamia lanceolata and Tsoongiodendron odorum, Soil Environ. Sci. 10 (2001) 289-292 (in Chinese with English abstract).

[19] McClaugherty C.A., Aber J.D., Melillo J.M., The role of fine roots in the organic matter and nitrogen budgets of two forested ecosystems, Ecology 63 (1982) 1481-1490.

[20] McClaugherty C.A., Aber J.D., Mellilo J.M., Decomposition dynamics of fine roots in forested ecosystems, Oikos 42 (1984) 378-386.

[21] McClaugherty C.A., Berg B., Cellulose, lignin and nitrogen concentrations as rate regulating factors in late stages of forest litter decomposition, Pedobiologia 30 (1987) 101-112.

[22] Santantonio D., Hermann R.K., Standing crop production, and turnover of fine roots on dry, moderate, and wet sites of mature Douglas-fir in western Oregon, Ann. Sci. For. 42 (1985) 113-142.

[23] Shan J.P., Tao D.L., Wang S., Study on fine root turnover in mixed forest of broadleaved and Korea pine in Changbai Mountain, Chin. J. Appl. Ecol. 4 (1993) 241-245 (in Chinese with English abstract).

[24] Taylor B.R., Parkinson D., Parsons W.F.J., Nitrogen and lignin content as predictors of litter decay rates: A microcosm test, Ecology 70 (1989) 97-104.

[25] Tian D.L., Zhu X.N., Cai B.Y., Litter-fall within ecosystem of Chinese fir plantations. Nutrient content and decay rate of litter- fall, Chin. J. Appl. Ecol. 9 (1989) 45-55 (in Chinese with English abstract).

[26] Tripathi S.K., Singh K.P., Nutrient immobilization and release patterns during plant decomposition in a dry tropical bamboo savanna, India, Boil. Fertil. Soils 14 (1992) 191-199.

[27] Usman S. Singh S.P., Rawat Y.S., Bargali S.S., Fine root decomposition and nitrogen mineralisation patterns in Quercus leucotrichophora and Pinus roxburghii forests in central Himalaya, For. Ecol. Manage. 131 (2000) 191-199.

[28] Van Vuuren, Berendse F., De Visser W., Species and site differences in the decomposition of litter and roots from wet heathlands, Can. J. Bot. 71 (1993) 167-173.

[29] Van Wesemael B., Litter decomposition and nutrient distribution in humus profiles in some Mediterranean forests in southern Tuscany, For. Ecol. Manage. 57 (1993) 99-114.

[30] Vogt K.A., Grier C.C., Vogt D.J., Production, turnover, and nutrient dynamics of above- and belowground detritus of world forests, Adv. Ecol. Res. 15 (1986) 303-377.

[31] Wen Q.X., Du L.J., Zhang X.H., Analysis for soil organic matter, China Agriculture Press, Beijing, 1984, pp. 256-271 (in Chinese).

[32] Yang Y.S., Studies on the sustainable management of Chinese fir plantations, Chinese Forestry Publishing House, Beijing, 1998, pp. 22-36 (in Chinese)

[33] Yang Y.S., Chen G.S., Guo J.F., He Z.M., Chen Y.X., Litter decomposition and nutrient release in a mixed forest of Cunninghamia lanceolata and Tsoongiodendron odorum, Acta Phytoecol. Sin. 26 (2002) 275-282.

[34] Yang Y.S., Chen G.S., Xie J.S., He Z.M., Chen Y.X., Huang R.Z., Nutrient cycling of $\mathrm{N}$ and $\mathrm{P}$ by a mixed forest of Cunninghamia lanceolata and Tsoongiodendron odorum in subtropical China, Acta Phytoecol. Sin. 26 (2002) 473-480 (in Chinese with English abstract).

[35] Yang Y.S., Chen G.S., He Z.M., Chen Y.X., Guo J.F., Production, distribution and nutrient return of fine roots in a mixed and a pure forest in subtropical China, Chin. J. Appl. Environ. Biol. 8 (2002) $223-233$.

[36] Yu X.T., Principle and technology on the planting mixed forests, Chinese Forestry Publishing House, Beijing, 1989, pp. 69-100 (in Chinese).

[37] Yu X.T., Silviculture of Chinese fir, Fujian Science and Technology Press, Fuzhou, 1996, 24-35 (in Chinese). 